
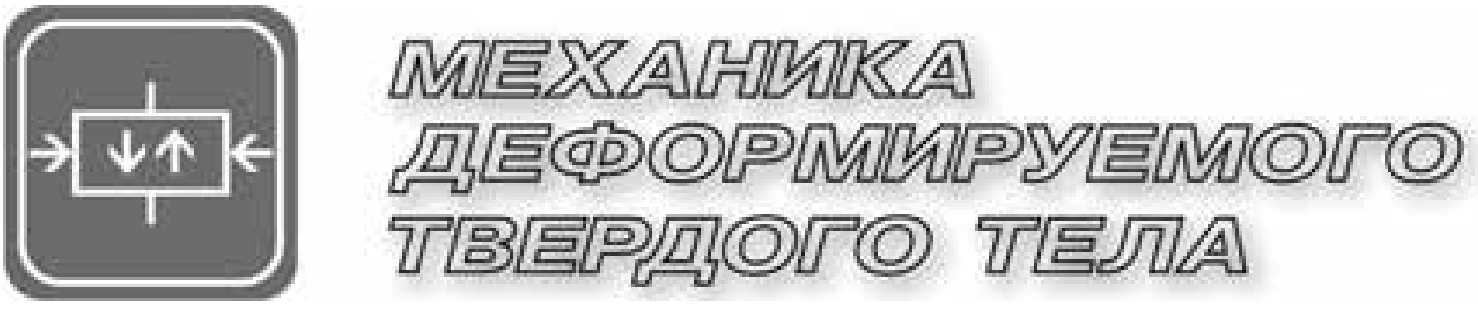

UDC 539.3

LEONENKO Denis V., D. Sc. in Phys. and Math., Assoc. Prof.

Professor of the Department "Structural Mechanics"

E-mail: leoden@tut.by

Belarusian State University of Transport, Gomel, Republic of Belarus

Received 02 December 2020.

\title{
ELASTIC BENDING OF A THREE-LAYER CIRCULAR PLATE WITH STEP-VARIABLE THICKNESS
}

The bending of a three-layer elastic circular plate with step-variable thickness is considered. To describe kinematics of asymmetrical in thickness core pack, the broken line hypotheses are accepted. In thin bearing layers, Kirchhoff's hypotheses are valid. In a relatively thick filler incompressible in thickness, Timoshenko's hypothesis on the straightness and incompressibility of the deformed normal is fulfilled. The formulation of the corresponding boundary value problem is presented. Equilibrium equations are obtained by the variational Lagrange method. The solution of the boundary value problem is reduced to finding three required functions in each section, deflection, shear and radial displacement of the median plane of the filler. An inhomogeneous system of ordinary linear differential equations is obtained for these functions. The boundary conditions correspond to rigid pinching of the plate contour. A parametric analysis of the obtained solution is carried out.

Keywords: three-layer circular plate, stepped thickness, bending of plates, elasticity, axisymmetric loading

DOI: https://doi.org/10.46864/1995-0470-2020-1-54-25-29

Introduction. The widespread use of thinwalled structural elements in construction and mechanical engineering necessitated the development of methods for their calculation. Static loading of single-layer circular plates was considered by both domestic [1,2] and foreign scientists [3]. Recently, many papers have been published on vibrations of homogeneous plates with variable thickness [4-6]. Deformation and vibrations of three-layer plates with constant thickness under static and dynamic loading, including on an elastic base, were studied in [7-11]. The behavior of a three-layer rod with an irregular boundary was studied in [12]. Here an axisymmetric transverse bending of a three-layer elastic circular plate with a step-variable thickness was considered.

Problem statement. The plate consists of three layers of different thickness. In the outer bearing layers, the Kirchhoff's hypothesis is accepted, and in the inner layer (filler), the Timoshenko's hypothesis is accepted. The thickness of the bearing layers can change stepwise along the radius of the plate (Figure 1). The filler is considered to be light, i.e. its operation is neglected in the tangential direction. In general, the broken line hypothesis holds for the core pack. On the plate contour, it is assumed that there is a rigid diaphragm that prevents the relative shift of the layers. At the layer boundaries, the movements are continuous.

The problem is formulated in a cylindrical coordinate system $r, \varphi, z$ associated with the median plane of the filler. The external surface of the first bearing layer is affected by axisymmetric distributed loads $q_{1}(r), q_{2}(r)$. The desired values are taken as the deflection of the plate $w_{l}(r)$, the relative shift in the filler $\psi_{l}(r)$, and the radial displacement of the coordinate plane $u_{l}(r)$ on each section $l$, which do not depend on the circumferential coordinate $\varphi$.

Based on the accepted hypotheses, for each of the two sections, the radial displacements in the layers $u_{r l}^{(k)}$ are expressed in terms of the desired functions $(l=1$, 2 - the section number): 


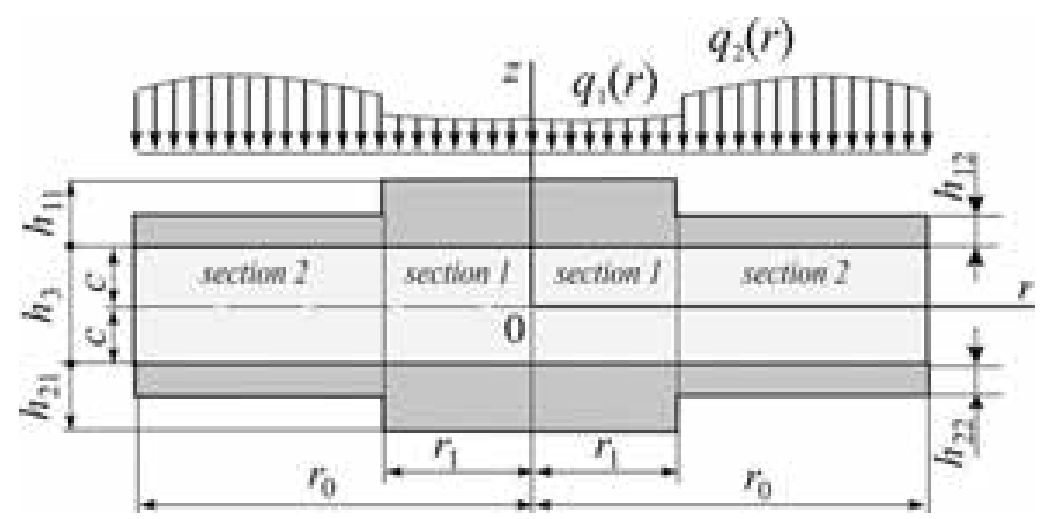

Figure 1 - Plate design scheme: $h_{k l}$ - thickness of the $k$-th layer, $h_{3}=2 c(k=1,2,3$ - number of layer $), \mathrm{m} ; r_{0}$ - plate radius, m; $r_{1}$ - radius of the first section, $\mathrm{m}$

$$
\begin{gathered}
u_{r l}^{(1)}=u_{l}+c \psi_{l}-z w_{l},,_{r} \quad\left(c \leq z \leq c+h_{1 l}\right) ; \\
u_{r l}^{(3)}=u_{l}+z \psi_{l}-z w_{l},{ }_{r}(-c \leq z \leq c) ; \\
u_{r l}^{(2)}=u_{l}-c \psi_{l}-z w_{l},,_{r}\left(-c-h_{2 l} \leq z \leq-c\right),
\end{gathered}
$$

where $z$ is the distance from the point under consideration to the median plane of the filler, the comma in the subscript indicates the operation of differentiation by the coordinate following it.

The plate equilibrium equations are derived from the Lagrange variational principle:

$$
\delta A-\delta W=0,
$$

where $\delta A=\delta A_{1}+\delta A_{2}$ is variation of the total work of external loads $q_{1}(r), q_{2}(r)$ and contour forces $T_{r}^{0}$, $H_{r}^{0}, M_{r}^{0}, Q^{0}$ :

$$
\begin{gathered}
\delta A_{1}=\int_{0}^{r_{1}} \int_{0}^{2 \pi} q_{1} \delta w_{1} r d r d \varphi+\int_{r_{1}}^{r_{0}} \int_{0}^{2 \pi} q_{2} \delta w_{2} r d r d \varphi ; \\
\delta A_{2}=\int_{0}^{2 \pi}\left(T_{r}^{0} \delta u+H_{r}^{0} \delta \psi+M_{r}^{0} \delta w,_{r}+Q^{0} \delta w\right) d \varphi,
\end{gathered}
$$

$\delta W-$ variation of internal elastic forces:

$$
\delta W=\sum_{l=1}^{2} \iint_{S_{l}}\left(\sum_{k=1}^{3} \int_{h_{k l}}\left(\sigma_{r}^{(k) l} \delta \varepsilon_{r}^{(k) l}+\sigma_{\varphi}^{(k) l} \delta \varepsilon_{\varphi}^{(k) l}\right) d z\right) d S,
$$

where $\sigma_{r}^{(k) l}$ - radial stress in the $k$-th layer on the section $l ; \delta \varepsilon_{r}^{(k) l}$ - variation of radial deformation in the $k$-th layer on the section $l ; \sigma_{\varphi}^{(k) l}$ - circumferential stress in the $k$-th layer on the section $l ; \delta \varepsilon_{\varphi}^{(k) l}$ - variation of circumferential deformation in the $k$-th layer on the section $l$.

Here, the integral is distributed over the entire median surface of the filler in each section $S_{1}, S_{2}$.

Substituting expressions (3) into relations (2), taking into account the Cauchy relations and displacements (1), and performing the corresponding transformations, we obtain system of equilibrium equations in forces describing elastic deformation of a three-layer circular plate with a light filler of step-variable thickness:

$$
\begin{gathered}
T_{r}^{l},{ }_{r}+\frac{1}{r}\left(T_{r}^{l}-T_{\varphi}^{l}\right)=0 ; \\
H_{r}^{l},{ }_{r}+\frac{1}{r}\left(H_{r}^{l}-H_{\varphi}^{l}\right)=0 ; \\
M_{r}^{l},_{r r}+\frac{1}{r}\left(2 M_{r}^{l},{ }_{r}-M_{\varphi}^{l}, r_{r}\right)=-q_{l},
\end{gathered}
$$

and boundary conditions $\left(r=r_{0}\right)$ :

$$
\begin{gathered}
T_{r}^{2}=T_{r}^{0} ; H_{r}^{2}=H_{r}^{0} ; M_{r}^{2}=M_{r}^{0} ; \\
M_{r}^{2},{ }_{r}+\frac{1}{r}\left(M_{r}^{2}-M_{\varphi}^{2}\right)=Q^{0} .
\end{gathered}
$$

Here, the generalized forces and moments in the layers are introduced as integrals over the thickness of each layer $(\alpha=r, \varphi)$ :

$$
\begin{aligned}
T_{\alpha}^{l} & \equiv \sum_{k=1}^{3} T_{\alpha}^{(k) l}=\sum_{k=1}^{3} \int_{h_{k l}} \sigma_{\alpha}^{(k) l} d z ; \\
M_{\alpha}^{l} & \equiv \sum_{k=1}^{3} M_{\alpha}^{(k) l}=\sum_{k=1}^{3} \int_{h_{k l}} \sigma_{\alpha}^{(k) l} z d z ; \\
H_{\alpha}^{l} & =M_{\alpha}^{(3) l}+c\left(T_{\alpha}^{(1) l}-T_{\alpha}^{(2) l}\right) ; \\
Q_{r}^{l} & =M_{r}^{l},{ }_{r}+\frac{1}{r}\left(M_{r}^{l}-M_{\varphi}^{l}\right) .
\end{aligned}
$$

After expressing the internal forces (6) in terms of the desired displacements (1) and substituting them in (4), we obtain a system of differential equations in displacements for each section:

$$
\begin{gathered}
L_{2}\left(a_{1 l} u_{l}+a_{2 l} \psi_{l}-a_{3 l} w_{l}, r_{r}\right)=0 ; \\
L_{2}\left(a_{2 l} u_{l}+a_{4 l} \psi_{l}-a_{5 l} w_{l},,_{r}\right)=0 ; \\
L_{3}\left(a_{3 l} u_{l}+a_{5 l} \psi_{l}-a_{6 l} w_{l},,_{r}\right)=-q_{l},
\end{gathered}
$$

where $L_{2}, L_{3}$ are second and third order differential operators, respectively [13]:

$$
\begin{gathered}
L_{3}(g) \equiv \frac{1}{r}\left(r L_{2}(g)\right),_{r} \equiv g,,_{r r}+\frac{2 g,_{r r}}{r}-\frac{g,_{r}}{r^{2}}+\frac{g}{r^{3}} ; \\
L_{2}(g) \equiv\left(\frac{1}{r}(r g){ }_{r}\right){ }_{r} \equiv g,_{r r}+\frac{g,_{r}}{r}-\frac{g}{r^{2}} .
\end{gathered}
$$

The coefficients ail for each section $l$ coincide in appearance with the equilibrium equations for a smooth three-layer circular plate:

$$
\begin{gathered}
a_{1 l}=\sum_{k=1}^{3} h_{k l} K_{k}^{+} ; a_{2 l}=c\left(h_{1 l} K_{1}^{+}-h_{2 l} K_{2}^{+}\right) ; \\
a_{3 l}=h_{1 l}\left(c+\frac{1}{2} h_{1 l}\right) K_{1}^{+}-h_{2 l}\left(c+\frac{1}{2} h_{2 l}\right) K_{2}^{+} ; \\
a_{4 l}=c^{2}\left(h_{1 l} K_{1}^{+}+h_{2 l} K_{2}^{+}+\frac{2}{3} c K_{3}^{+}\right) ; \\
a_{5 l}=c\left[h_{1 l}\left(c+\frac{1}{2} h_{1 l}\right) K_{1}^{+}+h_{2 l}\left(c+\frac{1}{2} h_{2 l}\right) K_{2}^{+}+\frac{2}{3} c^{2} K_{3}^{+}\right] ;
\end{gathered}
$$




$$
\begin{gathered}
a_{6 l}=h_{1 l}\left(c^{2}+c h_{1 l}+\frac{1}{3} h_{1 l}^{2}\right) K_{1}^{+}+ \\
+h_{2 l}\left(c^{2}+c h_{2 l}+\frac{1}{3} h_{2 l}^{2}\right) K_{2}^{+}+\frac{2}{3} c^{3} K_{3}^{+} \\
K_{k}^{+} \equiv K_{k}+\frac{4}{3} G_{k},
\end{gathered}
$$

where $K_{k}, G_{k}$ - volume and shear moduli of elasticity of layer materials, $\mathrm{Pa}$.

Solution of boundary value problem. To determine the displacements at each point of the plate, it is necessary to solve equations (7) in sections 1 and 2 . Then the desired displacements will be:

$$
\begin{gathered}
u(r)=u_{1}(r)+\left(u_{2}(r)-u_{1}(r)\right) H_{0}\left(r-r_{1}\right) ; \\
\psi(r)=\psi_{1}(r)+\left(\psi_{2}(r)-\psi_{1}(r)\right) H_{0}\left(r-r_{1}\right) ; \\
w(r)=w_{1}(r)+\left(w_{2}(r)-w_{1}(r)\right) H_{0}\left(r-r_{1}\right),
\end{gathered}
$$

where $H_{0}(r)$ is Heaviside step function [14].

We transform the system (7):

$$
\begin{gathered}
u_{l}=b_{1 l} w_{l},{ }_{r}+C_{1 l} r+C_{2 l} / r ; \\
\psi_{l}=b_{2 l} w_{l},_{r}+C_{3 l} r+C_{4 l} / r ; \\
w_{l},_{r r r r}+\frac{2}{r} w_{l},{ }_{r r r}-\frac{1}{r^{2}} w_{l},{ }_{r r}+\frac{1}{r^{3}} w_{l},_{r}=\tilde{q}_{l},
\end{gathered}
$$

where $C_{1 l}, C_{2 l}, C_{3 l}, C_{4 l}$ are integration constants; $\tilde{q}=q_{l} D_{l}$ :

$$
\begin{gathered}
D_{l}=\frac{a_{1 l}\left(a_{1 l} a_{4 l}-a_{2 l}^{2}\right)}{\left(a_{1 l} a_{6 l}-a_{3 l}^{2}\right)\left(a_{1 l} a_{4 l}-a_{2 l}^{2}\right)-\left(a_{1 l} a_{5 l}-a_{2 l} a_{3 l}\right)^{2}} ; \\
b_{1 l}=\frac{a_{3 l} a_{4 l}-a_{2 l} a_{5 l}}{a_{1 l} a_{4 l}-a_{2 l}^{2}} ; b_{2 l}=\frac{a_{1 l} a_{5 l}-a_{2 l} a_{3 l}}{a_{1 l} a_{4 l}-a_{2 l}^{2}} .
\end{gathered}
$$

The solution of the system (9) becomes [15]:

$$
\begin{gathered}
u_{l}=b_{1 l} w_{l},{ }_{r}+C_{1 l} r+C_{2 l} \frac{1}{r} ; \\
\psi_{l}=b_{2 l} w_{l},_{r}+C_{3 l} r+C_{4 l} \frac{1}{r} \\
w_{l}=C_{5 l}+C_{6 l} r^{2}+C_{7 l} \ln (r)+C_{8 l} r^{2} \ln (r)+w_{l}^{*} ; \\
w_{l}^{*}=\int \frac{1}{r} \int r \int \frac{1}{r} \int \tilde{q}_{l} r \mathrm{~d} r \mathrm{~d} r \mathrm{~d} r \mathrm{~d} r ; \\
w_{l,}=2 C_{6 l} r+C_{7 l} \frac{1}{r}+C_{8 l}(2 r \ln (r)+r)+w_{l}^{*},{ }_{r} ; \\
w_{l}^{*},_{r}=\frac{1}{r} \int r \int \frac{1}{r} \int \tilde{q}_{l} r \mathrm{~d} r \mathrm{~d} r \mathrm{~d} r \mathrm{~d} r .
\end{gathered}
$$

The problem of finding the functions $u(r), y(r)$, $w(r)$ (8) is closed by adding boundary conditions to $(10)$. When the contour of the plate is rigidly restrained $\left(r=r_{0}\right)$ :

$$
u_{2}=\psi_{2}=w_{2}=w_{2}, r=0 .
$$

In addition, the conditions of finiteness of displacements at the origin of coordinates with $r=0$ and the conditions at the boundary of thickness changes with $r=r_{1}$ must be satisfied:

- kinematic conditions:

$$
\begin{gathered}
w_{1}\left(r_{1}\right)=w_{2}\left(r_{1}\right) ; w_{1},{ }_{r}\left(r_{1}\right)=w_{2},{ }_{r}\left(r_{1}\right) ; \\
u_{1}\left(r_{1}\right)=u_{2}\left(r_{1}\right) ; \psi_{1}\left(r_{1}\right)=\psi_{2}\left(r_{1}\right) ;
\end{gathered}
$$

- natural boundary conditions:

$$
T_{r}^{1}=T_{r}^{2} ; M_{r}^{1}=M_{r}^{2} ; H_{r}^{1}=H_{r}^{2} ; Q_{r}^{1}=Q_{r}^{2} .
$$

Let us find the integration constants for each section.

Due to the limited nature of the proposed solution $\left(u_{1}, w_{1}, \psi_{1}, Q_{r}^{1}\right)$, at the origin $(r=0)$ of coordinates we must put:

$$
\begin{gathered}
C_{71}=0 ; C_{81}=0 ; \\
C_{21}=-\left.b_{11} \int r \int \frac{1}{r} \int \tilde{q}_{1} r \mathrm{~d} r \mathrm{~d} r \mathrm{~d} r\right|_{r=0} ; \\
C_{41}=-\left.b_{21} \int r \int \frac{1}{r} \int \tilde{q}_{1} r \mathrm{~d} r \mathrm{~d} r \mathrm{~d} r\right|_{r=0} .
\end{gathered}
$$

The conditions for rigid restraint of the contour (11) become:

$$
\begin{gathered}
u_{2}=\left.\left(b_{12} w_{2},{ }_{r}+C_{12} r+C_{22} \frac{1}{r}\right)\right|_{r=r_{0}}=0 ; C_{12} r_{0}+\frac{C_{22}}{r_{0}}=0 ; \\
\psi_{2}=b_{22} w_{2},{ }_{r}+C_{32} r+\left.\frac{C_{4 l}}{r}\right|_{r=r_{0}}=0 ; C_{32} r_{0}+\frac{C_{42}}{r_{0}}=0 ; \\
w_{2}=\left.\left(C_{52}+C_{62} r^{2}+C_{72} \ln (r)+C_{82} r^{2} \ln (r)+w_{2}^{*}\right)\right|_{r=r_{0}}=0 ; \\
C_{52}+C_{62} r_{0}^{2}+C_{72} \ln \left(r_{0}\right)+C_{82} r_{0}^{2} \ln \left(r_{0}\right)+\left.w_{2}^{*}\right|_{r=r_{0}}=0 ; \\
w_{2, r_{r}}=\left.\left(2 C_{62} r+C_{72} \frac{1}{r}+C_{82}(2 r \ln (r)+r)+w_{2}^{*}, r_{r}\right)\right|_{r=r_{0}}=0 ; \\
2 C_{62} r_{0}+C_{72} \frac{1}{r_{0}}+C_{82} r_{0}\left(2 \ln \left(r_{0}\right)+1\right)+w_{2}^{*},_{r}=0 .
\end{gathered}
$$

At the boundary of the thickness change $\left(r=r_{1}\right)$, we require the fulfillment of kinematic and natural boundary conditions (12):

$$
\begin{gathered}
w_{1}\left(r_{1}\right)=w_{2}\left(r_{1}\right) \\
C_{51}+C_{61} r_{1}^{2}+C_{71} \ln \left(r_{1}\right)+C_{81} r_{1}^{2} \ln \left(r_{1}\right)+\left.w_{1}^{*}\right|_{r=r_{1}}= \\
=C_{52}+C_{62} r_{1}^{2}+C_{72} \ln \left(r_{1}\right)+C_{82} r_{1}^{2} \ln \left(r_{1}\right)+\left.w_{2}^{*}\right|_{r=r_{1}} \\
w_{1, r_{r}}\left(r_{1}\right)=w_{2}, r_{r}\left(r_{1}\right) ; \\
2 C_{61} r_{1}+C_{71} \frac{1}{r_{1}}+C_{81}\left(2 r_{1} \ln \left(r_{1}\right)+r_{1}\right)+w_{1}^{*},\left._{r}\right|_{r=r_{1}}= \\
=2 C_{62} r_{1}+C_{72} \frac{1}{r_{1}}+C_{82}\left(2 r_{1} \ln \left(r_{1}\right)+r_{1}\right)+\left.w_{2}^{*} r_{r}\right|_{r=r_{1}} ; \\
u_{1}\left(r_{1}\right)=u_{2}\left(r_{1}\right) ; \\
\left.\left(b_{11} w_{1}, r_{r}-b_{12} w_{2}, r_{r}\right)\right|_{r=r_{1}}+\left(C_{11}-C_{12}\right) r_{1}+\left(C_{21}-C_{22}\right) \frac{1}{r_{1}}=0 ; \\
\psi_{1}\left(r_{1}\right)=\psi_{2}\left(r_{1}\right) ; \\
\left.\left(b_{21} w_{1}, b_{22} w_{2}, r_{r}\right)\right|_{r=r_{1}}+\left(C_{31}-C_{32}\right) r_{1}+\left(C_{41}-C_{42}\right) \frac{1}{r_{1}}=0 .
\end{gathered}
$$

The generalized forces (7) at the boundary of change in thickness of the plate are expressed in terms of the desired displacements and substituted into the conditions (12). Taking into account expressions (10), we obtain four more algebraic equations for determining unknown integration constants. Due to their awkwardness, they are omitted. 


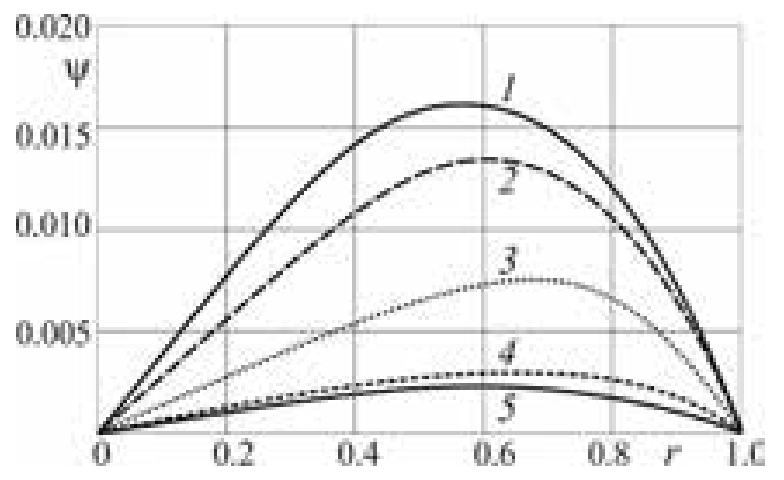

$a$

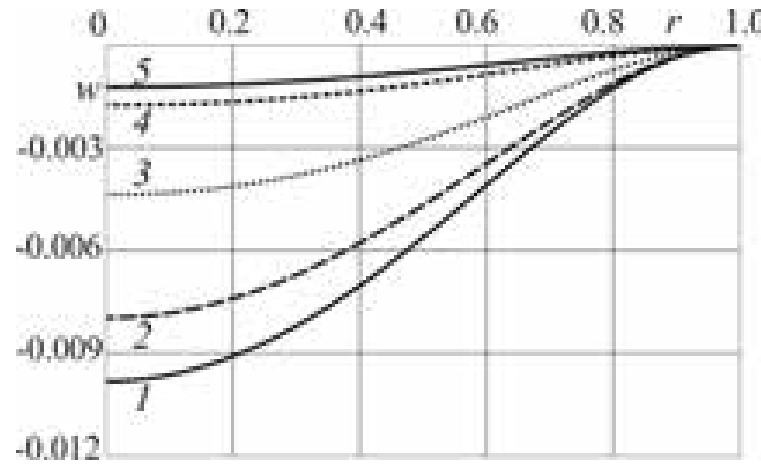

$b$

Figure 2 - Change in movement depending on the radius of the first section: $a$ - relative shift $\psi(r) ; b$ - deflection $w$ along the axis $r$, depending on the relative radius of the boundary sections $\left(1-r_{1}=0\right.$; $\left.2-r_{1}=0.25 ; 3-r_{1}=0.5 ; 4-r_{1}=0.75 ; 5-r_{1}=1\right)$

Combining expressions (13)-(15), we obtain a system of linear algebraic sixteenth order equations, from which we determine the integration constants $C_{11}, C_{12}, \ldots, C_{28}$.

Thus, the solution (10) and the integration constants (13)-(15) describe elastic displacements in a three-layer circular plate with step-variable thickness with a rigid pinching of the contour.

To verify the obtained analytical solution, a numerical study was performed.

Figure 2 shows graphs of change in movement depending on the radius of the first section. The plate contour is rigidly pinched. The calculation was performed for the D16T-fluoroplast-D16T core pack with layer thickness $c=0.15, h_{11}=h_{21}=0.04, h_{21}=h_{22}=0.02$. The intensity of the evenly distributed load $q=-100 \mathrm{kPa}$. Curves 1 and 5 correspond to a smooth plate that is symmetrical in thickness. These curves coincide with the curves calculated using the formulas from [16] for a plate with constant thickness in the absence of an elastic base (the elastic base stiffness coefficient is assumed to be $\kappa_{0}=0$ ).

With double thickening of the bearing layers, the displacements decreased by about 9 times (curves 1 and 5), while the total relative thickness of the plate changed slightly from 0.34 to 0.38 . The dependence of displacements on the value of the radius $r_{1}$ is nonlinear. A change in the step radius affects the deflection most strongly in the area of the center of the plate (curves 2 and 3). Its change in the area of a tightly pinched contour slightly affects the displacements (curves 4 and 5).
Conclusion. The solution (10), (13)-(15) given in the paper can be used to study any case of bending by an axisymmetric load of a three-layer circular plate with a light filler of step-variable thickness. Numerical analysis of the obtained solution revealed a pattern of changes in displacements from the radius of the boundary of thickness changes, which will make it possible to design plates of optimal sizes.

The work was financially supported by Belarusian Republican Foundation for Fundamental Research.

\section{References}

1. Kovalenko A.D. Kruglye plastiny peremennoy tolshchiny [Circular plates of variable thickness]. Moscow, Fizmatgiz Publ., 1959. 294 p. (in Russ.).

2. Dolgopolov V.M. Izgib krugloy ortotropnoy plastinki peremennoy tolshchiny [Bending of a circular orthotropic plate with variable thickness]. Nekotorye zadachi prikladnoy teorii uprugosti, 1971, pp. 44-50 (in Russ.)

3. Vivio F., Vullo V. Closed form solutions of axisymmetric bending of circular plates having non-linear variable thickness. International journal of mechanical sciences, 2010, vol. 52, iss. 9, pp. 1234-1252.

4. Kang J.H. Three-dimensional vibration analysis of thick, circular and annular plates with nonlinear thickness variation. Computers \& structures, 2003, vol. 81, iss. 16, pp. 1663-1675.

5. Liang B., Zhang S.-F., Chen D.-Y. Natural frequencies of circular annular plates with variable thickness by a new method. International journal of pressure vessels and piping, 2007, vol. 84, iss. 5, pp. 293-297.

6. Javanshir J., Farsadi T., Yuceoglu U. Free flexural vibration response of integrally-stiffened and/or stepped-thickness composite plates or panels. International journal of acoustics and vibration, 2014, vol. 19, no. 2, pp. 114-126.

7. Starovoitov E.I., Leonenko D.V. Termouprugoe deformirovanie trekhsloynoy krugloy plastiny poverkhnostnymi nagruzkami razlichnykh form [Thermoelastic deformation of three-layer circular plate by a surface loads of various forms]. Mechanics of machines, mechanisms and materials, 2018, no. 1(42), pp. 81-88 (in Russ.).

8. Jeon J.S., Hong C.S Bending of tapered anisotropic sandwich plates with arbitrary edge conditions. AIAA journal, 1992, vol. 30, no. 7, pp. 1762-1769.

9. Leonenko D. V. Svobodnye kolebaniya krugovykh trekhsloynykh plastin na uprugom osnovanii [Free vibrations of circular three-layer plates on an elastic base]. Ecological bulletin of research centers of the black sea economic cooperation, 2008, vol. 5, no. 3, pp. 42-47 (in Russ.).

10. Starovoitov E.I., Leonenko D.V., Tarlakovsky D.V. Resonance vibrations of a circular composite plates on an elastic foundation. Mechanics of composite materials, 2015, vol. 51, no. 5 , pp. 561-570. DOI: https://doi.org/10.1007/s11029-015-9527-2.

11. Starovoitov E.I., Leonenko D.V. Vibrations of circular composite plates on an elastic foundation under the action of local loads. Mechanics of composite materials, 2016, vol. 52, no. 5, pp. 665-672. DOI: https://doi.org/10.1007/s11029-016-9615-y.

12. Pleskatshevsky Yu.M., Starovoitova E.E. Izgib trekhsloynogo sterzhnya s neregulyarnoy granitsey [Bending of three-layer rod with irregular boundary]. Mechanics of machines, mechanisms and materials, 2008, no. 3(4), pp. 52-55 (in Russ.).

13. Starovoitov E.I. Vyazkouprugoplasticheskie sloistye plastiny $i$ obolochki [Viscoelastoplastic laminated plates and shells]. Gomel, Belorusskiy gosudarstvennyy universitet transporta Publ., 2002. 344 p. (in Russ.).

14. Korn G.A., Korn T.M. Mathematical handbook for scientists and engineers. Mineola, New York Dover Publications, 2000. $1151 \mathrm{p}$.

15. Kamke E. Differentialgleichnungen. Lösungsmethoden und Lösungen. I. Gewönliche Differentialgleichnungen. Leipzig, Akademische Verlagsgesellschaft Geest \& Portig K.-G., 1959.

16. Yarovaya A.V. Krugovaya trekhsloynaya plastina na uprugom osnovanii. Chast 1. Legkiy zapolnitel [Three-layer circular plate on an elastic foundation. Part 1. Lightweight filler]. Materialy, tekhnologii, instrumenty, 2005, vol. 10, no. 3, pp. 5-9 (in Russ.). 
Д.В. ЛЕОНЕНКО, д-р физ.-мат. наук, доц.

профессор кафедры «Строительная механика»

E-mail: leoden@tut.by

Белорусский государственный университет транспорта, г. Гомель, Республика Беларусь

Поступила в редакичию 02.12.2020.

\section{УПРУГИЙ ИЗГИБ КРУГОВОЙ ТРЕХСЛОЙНОЙ ПЛАСТИНЫ СТУПЕНЧАТО-ПЕРЕМЕННОЙ ТОЛЩИНЫ}

Рассмотрен изгиб упругой круговой трехслойной пластины ступенчато-переменной толщинь. Для описания кинематики несимметричного по толщчине пакета используются гипотезы ломаной линии. В тонких несущих слоях справедливы гипотезы Кирхгофа. В несжимаемом по толщине относительно толстом заполнителе выполняется гипотеза Тимошенко о прямолинейности и несжимаемости деформированной нормали. Приведена постановка соответствующей краевой задачи. Уравнения равновесия получены вариациионным методом Лагранжа. Решение краевой задачи сведено к нахождению трех искомых функций на каждом участке - прогиба, сдвига и радиального перемещеения срединной плоскости заполнителя. Для этих функиий получена неоднородная система обыкновенных линейных дифференциальных уравнений. Граничные условия соответствуют жесткому защчемлению контура пластины. Проведен параметрический анализ полученного решения.

Ключевые слова: трехслойная круговая пластина, ступенчатая толщина, изгиб пластин, упругость, осесимметричное нагружение

DOI: https://doi.org/10.46864/1995-0470-2020-1-54-25-29

\section{Список литературы}

1. Коваленко, А.Д. Круглые пластины переменной толщины / А.Д. Коваленко. - М.: Физматгиз. - 1959. - 294 с.

2. Долгополов, В.М. Изгиб круглой ортотропной пластинки переменной толщины / В.М. Долгополов // Некоторые задачи прикладной теории упругости: сб. науч. тр. - Саратов: Изд-во Сарат. политехнич. ин-та, 1971. - С. 44-50.

3. Vivio, F. Closed form solutions of axisymmetric bending of circular plates having non-linear variable thickness / F. Vivio, V. Vullo // Int. J. Mech. Sci. - 2010. - Vol. 52, iss. 9. Pp. 1234-1252.

4. Kang, J.H. Three-dimensional vibration analysis of thick, circular and annular plates with nonlinear thickness variation J.H. Kang // Comput. Struct. — 2003. - Vol. 81, iss. 16. Pp. 1663-1675.

5. Liang, B. Natural frequencies of circular annular plates with variable thickness by a new method / B. Liang, S.-F. Zhang, D.-Y. Chen // Int. J. Press. Vessels Pip. — 2007. — Vol. 84, iss. 5. - Pp. 293-297.

6. Javanshir, J. Free flexural vibration response of integrally-stiffened and/or stepped-thickness composite plates or panels / J. Javanshir, T. Farsadi, U. Yuceoglu // International Journal of Acoustics and Vibration. - 2014. - Vol. 19, no. 2. - Pp. 114-126.

7. Старовойтов, Э.И. Термоупругое деформирование трехслойной круглой пластины поверхностными нагрузками различных форм / Э.И. Старовойтов, Д.В. Леоненко // Механика машин, механизмов и материалов. - 2018. № 1(42). - C. 81-88.

8. Jeon, J.S. Bending of tapered anisotropic sandwich plates with arbitrary edge conditions / J.S. Jeon, C.S. Hong // AIAA Journal. - 1992. - Vol. 30, no. 7. - Pp. 1762-1769.
9. Леоненко, Д.В. Свободные колебания круговых трехслойных пластин на упругом основании / Д.В. Леоненко // Экологический вестник научных центров Черноморского экономического сотрудничества. - 2008. - Т. 5, № 3. С. $42-47$.

10. Старовойтов, Э.И. Резонансные колебания круговых композитных пластин на упругом основании / Э.И. Старовойтов, Д.В. Леоненко, Д.В. Тарлаковский // Механика композитных материалов. - 2015. - Т. 51, № 5. - С. 793-806.

11. Старовойтов, Э.И. Колебания круговых композитных пластин на упругом основании под действием локальных нагрузок / Э.И. Старовойтов, Д.В. Леоненко // Механика композитных материалов. - 2016. - Т. 52, № 5. - С. 943-954.

12. Плескачевский, Ю.М. Изгиб трехслойного стержня с нерегулярной границей / Ю.М. Плескачевский, Е.Э. Старовойтова // Механика машин, механизмов и материалов. 2008. - № 3(4) - - C. 52-55.

13. Старовойтов, Э.И. Вязкоупругопластические слоистые пластины и оболочки / Э.И. Старовойтов. - Гомель: БелГУТ, 2002. - 343 c.

14. Корн, Г. Справочник по математике для инженерных работников / Г. Корн, Т. Корн. - М.: Наука, 1973. - 832 с.

15. Камке, Э. Справочник по обыкновенным дифференциальным уравнениям / Э. Камке. - М.: Наука. - 1976. - 576 с.

16. Яровая, А.В. Круговая трехслойная пластина на упругом основании. Часть 1. Легкий заполнитель / А.В. Яровая // Материалы, технологии, инструменты. - 2005. - Т. 10, № 3. - C. 5-9. 